\title{
Campaign Climate
}

\section{A well-organized global grassroots campaign for climate protection could eclipse the IPCC in political influence.}

In September, the Intergovernmental Panel on Climate Change (IPCC) launched the

latest report on the physical science basis of climate change as part of its upcoming Fifth Assessment Report. In the weeks preceding the Stockholm launch meeting, the IPCC faced criticism from within the scientific community about how such assessments are prepared. Some researchers - including a number who have contributed to individual reports or even chaired working groups have openly called for a complete overhaul of the process.

The future of the IPCC will be discussed by its governing body at a meeting to be held in Batuma, Georgia, this month. In preparation for the event, the Secretary of the IPCC invited governments to "provide their views on which topics and questions should be addressed with respect to the future of the IPCC, as well as suggestions about the process the Panel may establish for efficient and timely consideration of the matter." The responses have been gathered and collated (see http://go.nature.com/ D7kI6v).

At the request of UN climate panel Co-Chair Thomas Stocker, of the University of Bern, the future of the IPCC is also expected to be the subject of public debate in December, when twenty-thousand-plus delegates descend upon San Francisco for the fall meeting of the American Geophysical Union. One issue is how to ease the burden of the many scientists who contribute - essentially voluntarily and without remuneration - to IPCC reports.

Another question is whether major IPCC reports released every five or six years have outlived their usefulness. More regular, targeted assessments could be more effective in guiding policies aimed at mitigating climate change, facilitating adaptation to its effects and preparing for potentially unavoidable climate-related impacts. In fact, several such targeted reports have already been produced by the IPCC. These include the recent Special Report on Managing the Risks of Extreme Events and Disasters to Advance Climate Change Adaptation (SREX) and the Special Report on Renewable Energy Sources and Climate Change Mitigation (SRREN). Some of the feedback from national governments solicited by the IPCC secretariat suggests that more such reports would be beneficial. It could well be that this is the way that the process will go: it is easier to roll out new information as it is generated, rather than squeezing it into the existing assessment cycle.

Many feel, however, that given the broad scientific consensus on climate change, what is needed now is concerted action at national and international levels, rather than just more information. One radical proposal championed by World Bank President Jim Kim is that climate protection advocates should seek to forge an international movement that includes concerned scientists, non-governmental organizations and civil society. Such a lobby - 'Campaign Climate, if you like - with genuine grassroots involvement would in the eyes of many be more than a match for climate change sceptics and vested interest groups, and perhaps more effective than the scientific community alone in applying pressure on national governments to act.

A specific suggestion is that such a broad-based movement could learn from, and perhaps even model itself on the global AIDS advocacy effort that has so successfully campaigned for global access to lifesaving antiretroviral drugs, and pushed for the human rights of those living with and affected by HIV.

In this issue (page 850), Jeremy Brecher of the Labor Network for Sustainability (based in Connecticut, USA) and Kevin Fisher, of Global Advocacy for HIV Prevention in New York, USA, explain how the International AIDS Conference (IAC), the twentieth of which will take place next year in Melbourne, Australia, has united civil society and scientists across the globe. Their thesis is that the achievements of the IAC provide those working for climate protection with an "important lesson on the power of global advocacy - and suggest a possible way to move beyond our current climate deadlock." They go on to explain how such a movement might first get off the ground, how it might be structured and how, once momentum had been gathered, the movement could give voice to those members of society who are concerned about climate change but feel that their views are being drowned out by the slick lobbying machine of certain powerful vested interests, including petrochemical giants.
Of course many people worry not only about climate change and its potential impacts, but also about environmental issues more generally. Take for example the issue of fossil fuel use for power generation. On page 859, Anna Petherick examines the case of Ecuador, whose president recently 'called time' on the Yasuní-ITT Initiative under which Ecuador would have been compensated for not extracting all of the hydrocarbon resources from beneath the Yasuní Biosphere Reserve. In addition to averting greenhouse gas emissions from deforestation and the burning of the oil, the Initiative would surely have helped to protect the biodiversity and relatively pristine environment of the reserve. But as Petherick explains, monies promised by the international community were not forthcoming in practice - at least not at the level or with the timeliness necessary to save the Initiative. Had the isolated and vulnerable Tagaere and Taromenane communities who live in the reserve had the vociferous support of an international, politically savvy campaign, such as the one proposed by Brecher and Fisher, things may have turned out differently.

Another area where pressure from a grassroots movement could galvanize action is that of risk management in relation to climate-related disasters. It is widely believed that extreme events such as droughts and floods are likely to increase in both frequency and intensity as global climate change bites. And yet, as noted by Lisa Palmer (page 857), international investment in disaster-risk management practices is tiny. As in the case of preventative medicine - and indeed as common sense suggests - capital directed towards preparing for the worst and taking steps to minimize the probable impacts of climate-related disasters before they strike is money well spent. As reported by Palmer, the lion's share of the money invested so far by the international community in risk management and preparedness has mostly gone to middleincome countries, with the poorest nations - the plight of Niger in the face of drought, desertification and famine is highlighted - losing out. Perhaps a global grassroots campaign such as that envisaged by Kim could make a real difference. 